\title{
The Illusion of Participatory Democracy: the AAA Organizes the Corn-Hog Producers*
}

Roger C. Lambert

AFTER FOUR YEARS OF DEPRESSION and more than a decade of economic difficulty, American farmers received promise of government assistance in the Agricultural Adjustment Act of May 1933. A sense of urgency surrounded development of the early commodity control measures as Congress delayed enactment of the measure until well into the growing season. Nevertheless, control programs which assured producers cash in 1933 in return for pledges to reduce future output quickly gained approval. As these projects were developed, the agricultural officials talked about creating an economic democracy in which the farm operatives would organize and develop their own production plans. Producer groups existed for some commodities and exercised an important influence role from the beginning. Other groups lacked organization and would receive guidance in developing representative organizations and control plans. Many livestock producers felt neglected during the hectic first months as the AAA worked with cotton and wheat farmers.

Federal assistance for hog growers was included in every major farm relief proposal debated after 1920. Because of the close relationship among corn, pork, and beef, AAA leaders considered a common program for the three to be desirable, but the cattlemen, denying they had a surplus problem, refused to come under the protection of the AAA. Caught in a serious cost-price

*A research grant from Arkansas State University helped in preparing this study for publication. 
squeeze the swine industry was in serious difficulties by 1933 . Hog prices in December 1932 were at the lowest level since 1878. At $\$ 2.95$ per 100 pounds in Chicago hogs were well below the price average for all farm products. ${ }^{2}$ The gross income from swine in 1932 was only one-third that of 1929 and the purchasing power was about two-fifths that of the 1910-1914 base period used to determine parity. ${ }^{2}$ This serious price fall resulted both from long term factors and the temporary influences of the depression.

Farmers refused to take measures to compensate for the decline in the foreign and domestic markets for pork. With corn prices low they tended to increase rather than decrease production. Both corn and hog producers facing low prices sought to maintain their income through an expansion of output which only served to push prices downward. The close relationship between hog and corn production complicated development of a control plan for either. ${ }^{3}$ Efforts to develop separate federal programs proved all but impossible. Secretary of Agriculture Henry A. Wallace of Iowa suggested that the delay in a relief project for the pork producers resulted "not from any lack of interest, but from an inability to see any way to help. ${ }^{\circ}$ Other major commodity interests had organized pressure groups and outlined general plans for assistance, but corn-hog farmers lacked both. Agricultural officials felt. for their own protection as well as for achieving broad producer cooperation, that the farmers must set up an organization which could present a program.

Corn Belt pressure, however, remained unorganized until the hog situation neared disaster and then appeared only after being induced and guided by the Department of Agriculture. ${ }^{5} \mathrm{~A}$ market

"'What's New in Agriculture," Yearbook of Agriculture, 1934, U.S. Department of Agriculture (Washington: U.S. Government Printing Office, 1935), 112. 113 ; U.S. Department of Agriculture, "The Agricultural Outlook for 1933," Staft of Bureau of Agricultural Economics, Miscellaneous Publication No. 156 (Wash. ington: 1933), 20-21.

2".Economic Situation of Hog Producers," Letter from the Secretary of Agriculture, 9 February 1933, 72nd Cong., 2d Sess., Senate Document No. 184, 1.

${ }^{3}$ C. F. Sarle, "Control of Hog Production by Reducing Corn Production," Confidential Plan. 12 May 1933. Agriculture Division of the National Archives. AAA Files. Record Group 145. All archival material hereafter cited is located in the Agriculture Division of the National Archives.

${ }^{4}$ Henry A. Wallace, New Frontiers (New York: 1934), 186.

s"'The plans of the Department have been stopped cold by the question as to whether the producers wish to co-operate." A. G. Black to the Corn-Hog Pro- 
upswing in the late spring of 1933 brought price increases for corn and some commodities but not for pork. Instead, excessive supplies in May confronted a continued low consumption rate and a rapidly increasing storage situation. A forecast of a 13 percent increase in sows for farrowing in the Corn Belt only served to cause additional concern. ${ }^{6} \mathrm{C}$. V. Gregory, editor of the Prairie Farmer, called a conference of corn-hog producers to meet in Chicago late in May. Secretary Wallace was wholeheartedly in support of the meeting and agreed to the request of the group that he appoint a committee to represent the interests of the hog farmer.' But the gathering failed to produce any concrete plan of action or permanent organization.

The need for a representative pressure group continued. J. S. Russell, farm editor of the Des Moines Register, warned that the lack of organization prevented consideration of their interests in Washington. ${ }^{8}$ When Russell conferred with Wallace, the Secretary informed him "that he was not going to impose any programs on any group. The wheat program had been asked for by the wheat growers-if the corn and hog farmers wanted a program, they would have to ask for it." " Roswell Garst, one-time partner of Secretary Wallace in producing seed corn, and Donald Murphy, editor of Wallaces' Farmer, joined Russell to organize Iowa producers.

It was no accident that Iowa farmers led the way in creating a corn-hog pressure organization. In mid-June representatives from various farm organizations and some 50 unaffiliated farmers met to establish a permanent state corn-hog committee, with Garst as

ducers Meeting, Des Moines, Iowa 18 July 1933. As quoted in D. A. FitzGerald. Corn and Hogs. Under the Agricultural Adjustment Act: Developments up to March 1951 (Washington: 1934), p. 10. Because of the quantity of corn and hogs produced in the ten state Corn Belt area, the Department always emphasized this region in dealing with the corn-hog problem. This was true in organizing a producer group, in working out a hog program and in trying to arouse producer support and response to the corn-hog programs. Although many of these farmers belonged to such organizations as the Farm Bureau, they did not have a separate commodity organization. Because of its organization on basic commodity lines, the AAA wanted separate product pressure groups. This constituted what they came to call economic democracy. p. 38 .

"Report of the Secretary of Agricuture," Yearbook of Agriculture. 1934.

'Des Moines Register, 24, 26 May 1933.

'Ibid.. 30 May 1933.

'Roswell Garst to the author, 1 August 1960. 
chairman. The group supported production control by the federal government and asked for immediate cash assistance. Possible programs included a reduction of corn acreage and a bonus on light hogs to reduce market supplies for $1934 .{ }^{10}$ More important to a future hog program than the recommendations was the initiation of a Corn Belt pressure group.

The Iowa committee served as the lever needed by the AAA to create the desired regional organization. On June 30, A. G. Black, chief of farm economics at Iowa State College and new head of the Corn-Hog Section of the AAA. informed leaders and farm groups in the remaining nine Corn Belt states about the Iowa action. He encouraged the creation of similar organizations in those states and called a regional conference to meet in Des Moines, lowa during the middle of July. "The Department and the lowa group took an active role in organizing the other states. Black sent members of the Iowa committee to guide the movement. Garst worked in Illinois and Indiana, while other Iowa representatives visited the remaining Corn Belt states. ${ }^{12}$ Once organization began, it proved so effective, Garst declared, that "in about a week we had corn-hog groups in every state that was prominent. $" 13$

On July 18, at the Des Moines meeting, Black emphasized to delegates of the ten Corn Belt states the importance of the organization:

I am trying to learn what farmers want and are willing to do and . . . will give heed to demands of the producers. Just what action is taken and how soon it is forthcoming will depend largely on what develops out of this conference.

Certainly it is not the purpose of Secretary of Agriculture Wallace and the farm act administration to force anything on the farmers. We are hoping they can formulate their own program. ${ }^{14}$

The group endorsed "regulation of the production of corn and hogs if necessary" to bring "hog prices up to a level with their pre-

10" lowa Corn and Hog Men Ask Action," Editorial, Wallaces' Farmer, 58 (24 June 1933), 4.

"Copies of Black telegrams. 30 June 1933, NA, RG 145; Des Moines Register. 2 July 1933.

${ }^{12} \cdot$ I I appreciate your sending Mr. Garst, of lowa, to the Meeting, and I may say that he made a good impression and was very helpful." J. S. Skinner to A. G. Black. 8 July 1933. NA, RG 145.

${ }^{13}$ Garst to author, 1 August 1960.

${ }^{14}$ Des Moines Register, 18 July 1933. 
war purchasing power."

Although the goal appeared simple, the method of achievement was not. A National Corn-Hog Committee of Twenty-Five, four appointed by Black and twenty-one by the local organizations, was created to develop a program. This positive action went beyond the desires of many farmers. Representatives of almost half of the states opposed any corn output control which implied opposition to the projected hog reduction. ${ }^{15}$ One local political leader in lowa charged Black and his group with "ramrodding" the conference and preventing delegates from expressing their opposition. ${ }^{10}$ The conference was not that controlled, but Black and the Administration certainly exerted great pressure to establish the National Committee, which immediately assumed responsibility for program development.

Several months of serious discussion had brought no real progress on a solution to the corn-hog problem. The impossibility of developing a joint pork-beef program acted as a serious obstacle. In the past, lack of agreement on a method and the absence of a producer group prevented action. Within the Administration a conflict between Secretary Wallace and his control-supporters and the export-dumping advocates of George N. Peek, Administrator of the AAA, delayed effective planning. Wallace had emphasized for a decade that surplus corn output stimulated hog production and made it "necessary to control corn acreage" to help the swine industry. He suggested payment of a bonus for acreage reduction and for light hogs. ${ }^{17}$ Peek denied that foreign prices or overproduction were major problems for the hog farmer. He wanted "a straightening up of the distributive system," particularly the processing industry. ${ }^{18}$ Peek refused to accept control of surplus production as the way to farm prosperity.

The June 1933 appointment of Black to head the Corn-Hog Section of the AAA made clear the ascendancy of the control people. Not only had Black been in "close touch" with Wallace on

's Ibid.. 19 July 1933.

${ }^{16}$ L. W. Drennen to Henry Wallace, 19 July 1933, NA. RG 145.

${ }^{17}$ Agricultural Emergency Act to Increase Farm Purchasing Power, Hearings before the Senate Agriculture Committee, 73d Cong., 1st Sess., March 1933, 45 and 141; "Benefits of the Allotment Plan," Editorial. Wallaces" Farmer, 58 (7 January 1933), 4.

${ }^{18}$ Agricultural Emergency Act to Increase Farm Purchasing Power, Hearings before the Senate Agriculture Committee, 73rd Cong., 1st Sess., March 1933, 76. 
production control measures but he had also been associated with other "corn belt economists and farm organization officials" in the early corn-hog conferences. Donald Murphy, editor of Wallaces' Farmer, regarded the appointment as proof that Wallace was "determined to take a personal part" in helping farmers to develop a corn-hog program. ${ }^{19}$

Development of the pressure organization supported this view. Wallace was involved at every stage. On June 10 Roswell Garst informed the Department of Agriculture about the meeting in Des Moines and suggested that the Iowa gathering could be of considerable value in working out a plan "if we know what program the Department of Agriculture has for the corn-hog situation." He insisted that his group was "particularly anxious to endorse only a program which he [Wallace] will. feel is sound and workable." Garst also asked Wallace how he could avoid embarrassing the Secretary with the "wrong suggestions." ${ }^{20}$ Both the organizational and program development make clear the close and continuous contact between the Department and the new leadership.

Two weeks before the National Corn-Hog Committee was created, AAA officials, farm representatives and processors conferred on the corn-hog situation. On July 5, Black met with Garst, Ed O'Neal, President of the American Farm Bureau. C. V. Gregory, Earl Smith, President of the Illinois Agricultural Association, and other producer representatives. They considered trade agreements with the processors but agreed "that a reduction in production of corn and hogs was necessary." The group was also concerned about the need for immediate cash relief. They agreed on a bonus for pregnant sows if a "special outlet" could be found for the pork. Garst, in Washington when the June pig survey appeared, pushed the "idea of killing the pregnant sows" because, as he wrote, "we would have raised so many pigs that fall that they wouldn't have paid the freight to market." 21 C. F. Sarle, AAA economist, had urged two months earlier the ne-

10"Plans for Hog Reduction." Editorial, Wallaces' Farmer, 58 (10 June 1933). 1.

${ }^{20}$ Garst to Paul Appleby, 19 June 1933. NA, RG 16; Garst to Wallace. 10 June 1933, NA, RG 145.

2"."Report of Conference with Producers," Chicago, 5 July 1933, NA, RG 145; Garst to author. 1 August 1960. 
cessity to reduce the number of brood sows farrowing in the fall of 1933. ${ }^{22}$ Considering the close contact between Garst and Wallace, the bonus idea might well have originated in the Department of Agriculture.

The producers and the AAA met with representatives of the processing industry on July 6,1933 . Everyone present agreed that the hog men had problems and on the desirability of selling pork surpluses to Russia. The processors, however, denied that any need existed for reducing hog production and opposed the bonus on piggy sows. ${ }^{23}$ Although subsequent talks were held with the packers, no agreements could be reached. The idea of emergency conditions shifted attention to a temporary program for 1933 . Garst wired Administrator Peek on July 6 to warn that the hog situation required "immediate action" and suggested a "credit export" of pork to Russia and a bonus program on one million sows. ${ }^{24}$

Suddenly-early in July-a sense of urgency, of almost impending doom, swept the swine industry. Over the next six weeks pleas for drastic measures of assistance came from North Dakota to Texas. Most petitioners emphasized the necessity for action and used the word "emergency." One suggested destruction of drought area pigs at "minimum expense." Significant was the attitude of the magazine called Wallaces' Farmer. The editor warned that "we are headed straight for big trouble in hogs. unless we get busy with a reduction program." He added: "We are going to be forced to take drastic steps to cut hog tonnage. ${ }^{25} \mathrm{Ap}$ pearing on July 8 , this editorial clearly presented the views of Secretary Wallace and his group in the AAA and among the producers. In fact, during the first years of the New Deal, the journal often anticipated Administration policy.

When the National Committee met with the AAA officials in Chicago late in July 1933, conditions seemed to merit the pessimistic descriptions and pleas for assistance. The parity price of

${ }^{22} \mathrm{C}$. F. Sarle, Confidential Memorandum on Methods of Control for Corn and Hogs, 12 May 1933, NA, RG 145.

${ }_{23}$ "Report of Conference between Producers and Processors," 6 July 1933. NA, $\operatorname{Rg} 145$.

${ }^{24}$ Garst and Charles E. Hearst to George N. Peek, 6 July 1933. NA. RG 145.

${ }^{25}$ J. H. Bennett to Wallace, 1 August 1933; W. H. McKinney to George N. Peek. 9 August 1933. NA. RG 145; "Headed for Trouble in Hogs," Editorial, Wallaces' Farmer. 58 (8 July 1933), 4. 
hogs was lower than that of any other major farm product. Slaughter numbers were up and prices were going down. Storage supplies were much higher than in 1932 and hogs to be slaughtered were also expected to be much greater. Complicating the picture, short feed supplies indicated that large numbers of cattle would be marketed to compete with pork. In short, the situation was nearing disaster. Agricultural officials wanted emergency relief, designed to provide immediate cash assistance and long range help in limiting hog supplies.

Agricultural economist C. F. Sarle presented the AAA view. Action was essential, but most suggestions did not meet the requirements. Sarle supported the bonus on sows and suggested that over a short period, beginning in August, a five dollar bonus could be paid on pregnant sows. A sufficiently large purchase, he hoped, might reduce next year's supplies by three million head. To prevent a lowering of prices the pork derived from the bonuses would be diverted out of "regular consumption channels." If the program worked effectively, prices could be increased by " 60 percent" over the remainder of the year. The National Committee accepted the plan but warned of several dangers. Publication of the plans might cause farmers "to defeat the program by breeding more sows." The Committee expressed more concern about the disposal plans. Government officials declared the plans to sell to Russia were complete except for a favorable Russian reply. ${ }^{20}$ Although this sale did not materialize, the pork was diverted to relief usage.

The plan was considerably altered by John Wilson, a committeeman from Ohio, who proposed "that the government buy 4 million pigs weighing between 40 and 140 pounds between, say, August 20th and October 1st." He estimated the purchase would cost $\$ 22$ million and expected a processing tax on hogs to pay the expenses. Meat procured from the young hogs could "be made into sausage and turned over to the Red Cross or sold to Russia." By greatly reducing tonnage for next year's market it would help raise swine prices. Although many committee members expressed reservations, Wilson, Garst and the AAA representatives maintained sufficient enthusiasm for all. The quick and energetic sup-

\footnotetext{
${ }^{20}$ Minutes of the Meeting of the National Corn-Hog Producers Committee. Chicago, 24 July 1933, NA, RG 145.
} 
port by Garst and the AAA indicated a similarity of view if not of prior planning. The AAA representatives were quick with estimates of how much this would raise prices. Garst insisted that the pig purchase should be tied to the sow bonuses in order to prevent farmers from holding their sows and thus defeat the whole emergency program. Garst also emphasized the Wallace view that this plan must be considered essentially a temporary relief measure which was to lead to a permanent control program. ${ }^{27}$

On July 27 Earl C. Smith, chairman of a special committee to work with the Department of Agriculture on emergency plans, reported unanimous agreement on the project. ${ }^{28}$ The National Committee program called for the purchase of four million young pigs weighing between 25 and 100 pounds and the payment of a $\$ 4$ bonus on one million piggy sows weighing over 275 pounds. A processing tax on all hogs over 235 pounds. except sows, would pay for the program. The project would provide immediately "substantial and necessary cash" to the farmers. The Committee pledged a long-term corn-hog control plan would be ready by the time the emergency purchases were completed. ${ }^{29}$ As announced in mid-August the final plan called for the purchase of one million sows and four million pigs. ${ }^{30}$ It was expected to provide immediate cash to corn-hog farmers, a similar emergency assistance as other programs gave to cotton and wheat farmers. More important was the anticipated long-range reduction in output and the understanding that this project would be followed by a longterm corn-hog restriction program.

That both the so-called producer organization and the program seem to have originated in Washington was no surprise. The commitment of agricultural officials to what they called "economic" democracy was more than verbal. They envisaged organzied farmers developing their own programs with the assistance of the professionals. Unlike cattlemen and other major commodity groups, hog producers were too unorganized to exert

${ }^{2}$ Ibid.

${ }^{28} \mathrm{C}$. C. Davis to George Peek: Memorandum on Call from Earl C. Smith, 27 July 1933, NA, RG 145.

${ }^{20 "}$ "The Report and Recommendations of the national Corn and Hog Committee," Probably prepared on 27 July 1933. NA, RG 145.

${ }^{30}$ Farmers did not cooperate with the control phase of the program as they sold only 222,149 brood sows against over six milion pigs. FitzGerald, Corn and Hogs. 35. 
much influence on present plans. It was to be expected that Wallace, from the Corn Belt, would bring in men with similar views and many from his own area. It was equally obvious that he would rely upon old friends from business and publishing to organize and present the needed pressure group and plans. That AAA economists had already considered many of the ideas that producer conferences suggested was also natural, but with more experience the representatives, it was expected, would take a larger part in development. For editors and businessmen to take the lead in organizing fitted the traditions of farm organization.

That the AAA did not want to force an unwanted program on the farmers should not be seriously questioned. On both philosophical and practical grounds they wanted farmer support and involvement. Whether their commitment to participating democracy was that of Jefferson, who left man "freely . . . to self-government," or Du Pont de Nemours, who loved mankind "as infants whom you are afraid to trust without nurses" need not be debated. Wallace believed that he meant it as Jefferson, that American farmers were developing "a true economic democracy, designed to rescue our political democracy from the danger of hollow mockery." He argued that farmers, through the methods of the AAA and by developing their own programs, were creating "a process of economic self-government" just as the forefathers had developed a system of political self-government. ${ }^{31}$ Because of twentieth century complexity he believed that farmers would need to cooperate and would need the advice of government experts. On a purely practical basis, the experience of the AAA with the cotton plow-up demonstrated the potential for trouble with emergency reduction measures. Wallace insisted that he had anticipated the attacks against the "slaughter of the innocents" as the pig slaughter was described.

Whether or not AAA officials expected the intensity of the emotional protest, they were aware of the political dangers of such a program. The advantages to the agricultural planners of a producer organization that apparently could speak for the farmer and that could give the illusion of actively planning farm programs were obvious. Organization of the corn-hog farmers might well take some political heat off the official planners.

"Wallaces' Farmer. 60 (29 September 1934). 5; 60 (19 January 1935), 1. 
Copyright of Annals of Iowa is the property of State of Iowa, by \& through the State Historical Society of Iowa and its content may not be copied or emailed to multiple sites or posted to a listserv without the copyright holder's express written permission. However, users may print, download, or email articles for individual use. 